\title{
ANALISIS SIFAT PENYERAPAN AIR DAN INDEKS NYALA API PADA PAPAN KOMPOSIT YANG DI PERKUAT SERAT DAUN PANDAN DURI DAN LIMBAH SERBUK GERGAJI KAYU SENGON DENGAN RESIN POLYESTER \\ Analysis of water absorption and flame index of the composite boord reinforced \\ by pandanus tectorius fiber and sengon wood sawdust waste with polyester \\ resin
}

\author{
Saiful Bachtiar ${ }^{1 *}$, Emmy Dyah Sulistyowati. ${ }^{2}$, Agus Dwi Catur $^{3}$ \\ ${ }_{1,2,3}$ Jurusan Teknik Mesin Fakultas Teknik Universitas Mataram \\ Jalan Majapahit No. 62 Mataram - NTB \\ Email: bachtiar@ymail.com
}

\begin{abstract}
The use of composite materials as an alternative to metallic materials in the field of engineering more widespread, not only as an interior daneksterior in the automotive field but also extended to other areas such as property and architecture is to reduce the incidence of fire one only to find a replacement for wood as a raw material of houses and buildings with other alternative materials are more fire resistant, the material need not be limited in mechanical strength, but also on the physical properties. Therefore, the aim of this study was to analyze the absorption properties of water and fire index in the fiber-reinforced composite board pandanus leaves thorns and wood sawdust filler sengon with polyester resin as matriknya.

Analysis of the absorption properties of the water carried by the ASTM D 5529 with a variation of the length of time of immersion (10,20, and 30 days) and the fiber volume fraction (0\%, 10\%, 20\% and 30\%). Testing index of the flame using ASTM E1321 with long burning time of 10 minutes. To test the effect of soaking time and a fiber volume fraction of the weight gain, volume, and density on the board fiber composite pandanus thorns with $10 \%$ filler wood sawdust sengon diguanakn Two Ways Analysis Of Variance, and the effect of fiber volume fraction to index Flash Fire is used One Ways Analysis Of Variance.

The results showed that the water absorption is affected by fiber volume fraction and longer soaking time. The largest percentage of water absorption occurs in the volume fraction of $30 \%$ with long soaking time of 30 days is $24.41 \%$. Similarly, the highest percentage swelling occurs in composite board with a volume fraction of $30 \%$ with a 30-day long soaking time is $11: 22 \%$. Then the flame to the percentage of the index without fiber composite board has a greater percentage is $167.03 \%$. By contrast the percentage of board composite index gained shortest of composite board with a fiber volume fraction of $30 \%$ ie $70.25 \%$ composite board with a fiber volume fraction of $30 \%$ also have a flame index is lower than the comparison is with wood composites sengon.
\end{abstract}

Keywords: Composite, Pandanus Tectorius, Water Absorption, Flame Index .

\section{LATAR BELAKANG}

Dewasa ini kemajuan ilmu pengetahuan dan teknologi berkembang sangat pesat, terutama dibidang material dan bahan baik di bidang material logam maupun non logam. Hal ini dapat dilihat dari perkembangan industri otomotif dan material yang semakin pesat, dengan peningkatan akan kebutuhan interior mobil, bahan-bahan bangunan seperti jendela, dan pintu yang semakin baik dari segi fisik maupun sifat mekaniknya. Hal ini tentunya menjadi tantangan tersendiri untuk para peneliti khususnya di bidang material untuk memenuhi kebutuhan material yang memiliki karakteristik yang lebih baik, murah, dan ramah lingkungan.
Salah satu cara untuk memenuhi kebutuhan material tersebut yaitu dengan mengunakan komposit. Perkembangan teknologi komposit saat ini sudah mulai mengalami pergeseran dari bahan komposit berpenguat serat sintetis menjadi bahan komposit berpenguat serat alam. Penggunaan serat alam sebagai bahan komposit yang aplikasinya sebagai interior mobil, dan bahan bangunan seperti pintu jendela didasarkan karena beberapa kelebihan yang dimiliki, diantaranya yaitu memiliki sifat mekanik yang tinggi, ramah lingkungan, lebih tahan api dan biaya pembuatan yang relatif murah. Komponen yang dibuat dari komposit harganya dapat turun hingga $50 \%$ jika dibandingkan dengan produk bahan logam [1]. 
Sedangkan untuk limbah serbuk kayu bisa menjadi produk yang bermanfaat. Kebutuhan kayu untuk industri perkayuan di indonesia diperkirakan sebesar 70 juta $\mathrm{m}^{3}$ pertahun dengan kenaikan rata-rata sebesar $14,2 \%$ pertahun sedangkan produksi kayu bulat diperkirakan hanya sebesar 25 juta $\mathrm{m}^{3}$ per tahun. Dengan demikian terjadi defisit sebesar [2].

Seperti yang telah diuraikan pada prospek aplikasi komposit serat alam di atas, bahwa inovasi pengembangan komposit saat ini sudah banyak diaplikasikan di berbagai bidang, baik di bidang otomotif ataupun struktur bangunan yang tidak hanya terbatas pada bagian interior tetapi juga pada bagian eksteriornya terutama bagian-bagian yang sangat rentan dengan dengan kondisi lingkungan basah dan kelembaban tinggi yang bisa mempengaruhi kondisi fisik dari komposit.

Oleh karena itu, sangatlah penting untuk menganalisis sifat penyerapan air pada papan komposit yang di perkuat serat daun pandan duri dengan filler limbah serbuk gergaji kayu sengon sehingga dapat diketahui perubahan sifat yang terjadi pada papan komposit tersebut baik itu perubahan berat, volume serta berat jenis yang disebabkan penyerapan air pada komposit tersebut.

Sedangkan pada pengujian ketahanan nyala api dimana bahan polimer termasuk yang sangat mudah menyala seperti seluloid yang dapat habis terbakar sendiri secara spontan walau api dipadamkan. Selain itu kebutuhan penyebaran nyala api khususnya digunakan untuk bahan interior, upaya untuk mengefisiensikan penggunaan material logam dan kayu dengan mencari alternatif yang mempunyai sifat yang sama perlu di tingkatkan. Maka berdasarkan uraian-uraian diatas, timbul suatu pemikiran untuk menganalisis sifat penyerapan air dan indeks nyala api pada papan komposit yang di perkuat serat daun pandan duri dan limbah serbuk gergaji kayu sengon dengan resin polyester sebagai matriknya.

\section{LANDASAN TEORI}

Komposit merupakan gabungan dari dua atau lebih bahan yang berbeda yang digabung atau dicampur menjadi satu secara makroskopis. Bahan komposit pada umumnya terdiri dari dua unsur yaitu serat (fiber) sebagai bahan pengisi dan bahan pengikat serat-serat tersebut yang disebut matrik. Penggunaan serat untuk menentukan karakteristik bahan komposit seperti: kekakuan, kekuatan serta sifat-sifat mekanis lainnya. Sebagai bahan pengisi, serat digunakan untuk menahan sebagian besar gaya yang bekerja pada bahan komposit, matrik sendiri mempunyai fungsi melindungi dan mengikat serat agar dapat bekerja dengan baik terhadap gaya-gaya yang terjadi.

\section{Unsur Penyusun Komposit}

Pada umumnya bahan komposit terdiri dari dua unsur, yaitu serat (fiber) dan bahan pengikat serat tersebut yang disebut matrik.

\section{a. Serat}

Salah satu unsur penyusun bahan komposit adalah serat. Serat inilah yang terutama menentukan karakteristik bahan komposit, seperti kekakuan, kekuatan serta sifat-sifat mekanik lainnya. Serat inilah yang menahan sebagian besar gaya-gaya yang bekerja pada bahan komposit.

\section{b. Matriks (Resin)}

Matriks (resin) dalam susunan komposit bertugas melindungi dan mengikat serat agar dapat bekerja dengan baik. Matriks harus bisa meneruskan beban dari luar ke serat. Umumnya matriks terbuat dari bahan-bahan yang lunak dan liat. Polymer (plastik) merupakan bahan umum yang biasa digunakan.

\section{c. Pengisi (Filler)}

Pengisi adalah bahan yang banyak digunakan untuk ditambahkan pada bahan polymer untuk meningkatkan sifatsifatnya dan pemerosesan untuk mengurangi ongkos produksi. Filler dalam komposit digunakan sebagai penguat matrik resin polymer.

\section{METODE PENELITIAN \\ Bahan dan Alat Penelitian}

Bahan yang digunakan dalam penilitian ini adalah serat Pandan duri dan serbuk gergaji kayu sengon resin polyester, katalis.

Daun pandan duri didapatkan di pinggiran sungai dan kemudian untuk mendapatkan serat pandan duri dilakukan proses pembusukan yaitu direndam selama 10 hari setelah itu dilakukan pemisahan antara daging dengan serat dengan cara dikeruk menggunakan sendok secara perlahan agar serat tidak cepat putus pada saat dipisahkan dengan dagingnya. Serat pandan duri yang sudah didapat kemudian direndam dalam larutan $\mathrm{NaOH}$ dengan konsentrasi 4\% (berat) selama 2 jam. Setelah direndam dalam larutan $\mathrm{NaOH}$ serat sabut kelapa dicuci dengan menggunakan air PDAM sampai bersih dan dikeringkan dibawah sinar matahari. Kemudian serat daun pandan duri dipotong dengan panjang $30 \mathrm{~mm}$. 
Serbuk gergaji kayu sengon yang di dapat dari tempat pemotongan kayu, dijemur terlebih dahulu untuk mangurangi kandungan airnya selama 3 hari. Serbuk gergaji kayu sengon diayak dengan ukuran 40 mesh sehingga ukuran serbuknya seragam.

\section{Proses pembuatan benda uji}

\section{a. Pencampuran bahan}

Pencampuran bahan menggunakan serbuk gergaji kayu sengon sebanyak $10 \%$ dengan ayakan 40 mesh dan serat daun pandan duri dengan panjang serat $3 \mathrm{~cm}$ dengan fraksi volume serat sebanyak $0 \%$, $20 \%$, dan $30 \%$.

\section{b. Proses pencetakan benda uji/spesimen}

Persiapan alat dan bahan kemudian Pengolesan kit mobil pada cetakan untuk memudahkan pengambilan benda uji dari cetakan setelah mengalami proses pengeringan, penempatan masing-masing bahan kedalam wadah pengaduk sesuai dengan komposisi yang telah di tentukan penuangan sebagian resin polyester dan katalis sesuai dengan komposisi ke dalam wadah pengaduk kemudian aduk hingga campuran resin, serat dan serbuk kayu merata selanjutnya tuang ke dalam cetakan, penutup dengan plat besi bagian atasnya yang bertujuan agar void yang kelihatan dapat diminimalkan jumlahnya yang kemudian dilakukan pengepresan dengan menggunakan alat penekan, proses pengeringan dibawah sinar matahari, proses ini dilakukan sampai benar-benar kering \pm 24 jam dan apabila masih belum benar-benar kering maka proses pengeringan dapat dilakukan lebih lama, proses pengambilan komposit dari cetakan dapat menggunakan pisau ataupun cutter, komposit yang telah dicetak dibentuk menjadi benda uji sesuai dengan standar masing-masing pengujian.

\section{Pengujian Indeks Nyala Api}

Pengujian karakterisasi nyala api dilakukan berdasarkan prosedur standar ASTM-E84. Standar uji ini adalah membandingkan karakter hasil pembakaran permukaan suatu material bahan bangunan yang dapat diaplikasikan sebagai dinding dan langit-langit.

Ukuran/dimensi spesimen komposit pada penelitian ini panjangnya $30 \mathrm{~cm}$, tebalnya $5 \mathrm{~cm}$, dan lebarnya $3,1 \mathrm{~cm}(30 \mathrm{~cm} x$ $5 \mathrm{~cm} \times 3,1 \mathrm{~cm})$ atau tidak habis terbakar selama 10 menit (Rahman, 2010).

Pengujian seluruh spesimen dihitung dengan persamaan :

$I=P 1 P 2 \times 100$

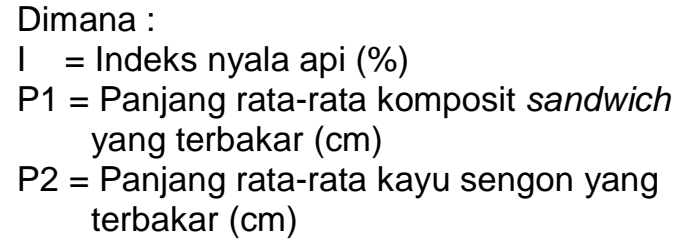

\section{Analisis Uji Penyerapan Air}

Penyerapan air komposit merupakan kemampuan komposit dalam menyerap air dalam waktu tertentu. Penyerapan air ditandai dengan perubahan berat, volume dan berat jenis komposit. Pengujian penyerapan air ini dilakukan dengan standar ASTM D 5229, Spesimen uji ditimbang dengan timbangan digital dengan ketelitian 0,01 gram dan uji pembengkakan dilakukan dengan mengukur volume menggunakan jangka sorong dengan ketelitian 0,01 $\mathrm{mm}$, kemudian spesimen direndam selama 30 hari, setelah itu komposit ditimbang dan diukur lagi untuk mengetahui perubahan yang terjadi.

Ukuran spesimen dalam penelitian ini juga mengacu pada ASTM D 5229 yaitu dengan panjang $50 \mathrm{~mm}$, lebar $50 \mathrm{~mm}$ dan ketebalan $5 \mathrm{~mm}$.

Grafik hasil pengujian dapat dibuat dari data sebelum dan sesudah perendaman kemudian dilakukan perhitungan dengan persamaan-persamaan ASTM D 5229 berikut

$$
\text { a) Penyerapan air }=\frac{W-D}{D} \times 100 \%
$$

$$
\begin{aligned}
& \text { Dimana : } \\
& \begin{aligned}
\mathrm{W} & =\text { Wet weight } / \text { berat basah }(\mathrm{gr}) \\
D & =\text { Dry weight } / \text { berat kering }(\mathrm{gr})
\end{aligned}
\end{aligned}
$$

b) Pembengkakan $=\frac{v_{1}-v_{0}}{v_{0}} \times 100 \%$

Dimana :

$\mathrm{v}_{0}=$ Volume awal (mm3)

$\mathrm{v}_{1}=$ Volume akhir $(\mathrm{mm} 3)$

c) $\rho=\frac{m}{v}\left(\mathrm{gr} / \mathrm{mm}^{3}\right)$

d) Perubahan $\rho=\frac{\rho_{1}-\rho_{0}}{\rho_{0}} \times 100 \%$

$$
\begin{aligned}
& \text { Dimana: } \\
& \mathrm{m}=\text { massa }(\mathrm{gr}) \\
& \mathrm{v}=\text { volume awal (mm3) } \\
& \rho_{0}=\text { massa jenis awal }(\mathrm{gr} / \mathrm{mm} 3) \\
& \rho_{1}=\text { massa jenis akhir }(\mathrm{gr} / \mathrm{mm} 3)
\end{aligned}
$$

\section{HASIL DAN PEMBAHASAN}

Pengujian Sifat Penyerapan Air Pada Papan Komposit Serat Daun Pandan Duri.

Dari hasil pengujian penyerapan air papan komposit yang diperkuat serat daun pandan duri dan filer limbah serbuk gergaji 
kayu sengon dengan variasi fraksi volume serat $10 \%, 20 \%$, dan $30 \%$ dan lama waktu perendaman selama 30 hari didapat data yang ditunjukkan pada tabel dibawah ini:

Grafik 4.1 Dari data uji pertambahan berat papan komposit serat daun pandan duri dengan lama waktu perendaman selama 30 hari didapat grafik sebagai berikut:

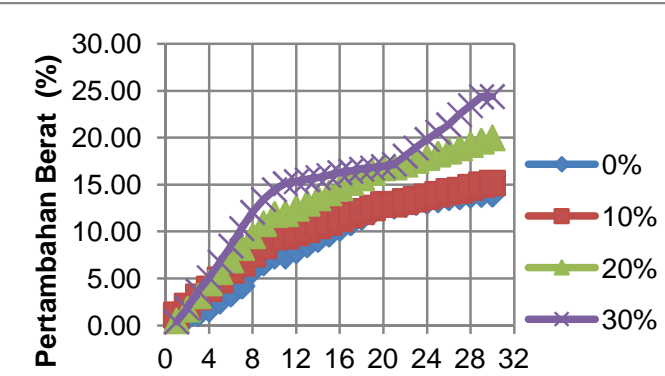

Lama Waktu Perendaman (Hari)

Gambar 1. Grafik pertambahan berat pada papan komposit terhadap fraksi volume serat dan lama waktu perendaman selama 30 hari.

\section{Pengujian Pertambahan Berat Pada Papan Komposit Serat Daun Pandan Duri.}

Dari gambar grafik di atas menunjukkan perbedaan pertambahan berat yang terjadi pada papan komposit terhadap fraksi volume serat dan lama waktu perendaman yang berbeda-beda. Dari grafik 1 dapat di lihat bahwa pertambahan berat pada papan komposit dipengaruhi oleh variasi fraksi volume serat. Penyerapan air papan komposit semakin meningkat seiring dengan bertambahnya fraksi volume serat. Selain variasi fraksi volume serat, lama waktu perendaman pada papan komposit juga mempengaruhi penyerapan air pada papan komposit, maka makin lama perendaman dilakukan maka penyerapan air pada komposit makin besar pertambahan berat pada papan komposit menandakan adanya penyerapan air pada papan komposit. Pada waktu perendaman air akan meresap dan menempel pada serat, filer, maupun pada matrik komposit sehingga menambah penyerapan air pada papan komposit.

Dapat kita liat dalam grafik 1 titik konstan yang terjadi pada preses pertambahan berat pada papan komposit terjadi pada perendaman selama 20-30 hari setelah itu tidak terjadi pertambahan berat lagi.

Pengaruh Variasi Volume Serat dan lama waktu perendaman Terhadap Pertambahan berat Pada Papan Komposit Serat Daun Pandan Duri.

Pada pengujian pertambahan berat papan komposit serat daun pandan duri terdapat perbedaan berat yang terjadi dimana pada setiap fraksi volume serat memiliki nilai penyerapan air yang berbeda-beda. Hal ini menandakan bahwa adanya pengaruh dari variasi fraksi volume serat terhadap penyerapan air dari komposit tersebut. Grafik pada gambar 1 menunjukkan bahwa untuk lama waktu perendaman selama 10, 20, dan 30 hari komposit tanpa serat atau $0 \%$ serat memiliki nilai penyerapan air paling kecil yaitu $7.41 \%$, $12.69 \%$, dan $24.41 \%$ sedangkan nilai penyerapan air yang terbesar terjadi pada fraksi volume serat $30 \%$ yaitu $14.48 \%$, $16.96 \%$, dan $24.41 \%$. Oleh karena itu fraksi volume serat sangat berpengaruh tehadap penyerapan air komposit, dimana semakin banyak serat yang ditambahkan maka penyerapan air akan semakin meningkat.

\section{Data Analisis Of Varian (Anova) Dua Faktor.}

Data penyerapan air komposit dianalisis dengan menggunakan two ways analysis of variance, untuk mengetahui pengaruh dari variasi fraksi volume serat dan lama waktu perendaman serat daun pandan duri dan serbuk gergaji kayu sengon dengan resin polyester terhadap penyerapan air.

Tabel 1. Tabel Two Ways Analysis Of Variance dengan $\alpha=0.05$.

\begin{tabular}{llllll}
\hline Pengaruh variasi & $\begin{array}{l}\text { Jumlah } \\
\text { Kuadrat (SS) }\end{array}$ & $\begin{array}{l}\text { Derajat } \\
\text { Kebebasan (DB) }\end{array}$ & $\begin{array}{l}\text { Rataan } \\
\text { Kuadrat (MS) }\end{array}$ & $\begin{array}{l}\text { F Hitung F tabel } \\
\text { (Fhit) }\end{array}$ & (Ft) \\
\hline Volume Serat & 6.98 & 2 & 3.49 & 101.57 & 3.4 \\
\hline Lama Waktu Perendaman & 6.14 & 3 & 2.05 & 101.57 & 3.01 \\
\hline Interaksi & 0.67 & 6 & 0.11 & 3.25 & 2.51 \\
\hline Galat & 0.82 & 24 & 0.03 & & \\
\hline Jumlah & 14.61 & 35 & & & \\
\hline
\end{tabular}


Berdasarkan tabel 1 dapat disimpulkan bahwa Fraksi Volume Serat, Lama waktu perendaman, dan interaksinya berpengaruh

Hasil Pengujian Pembengkakan Pada terhadap berat komposit pada penyerapan air.

\section{Papan Komposit Serat Daun Pandan Duri.}

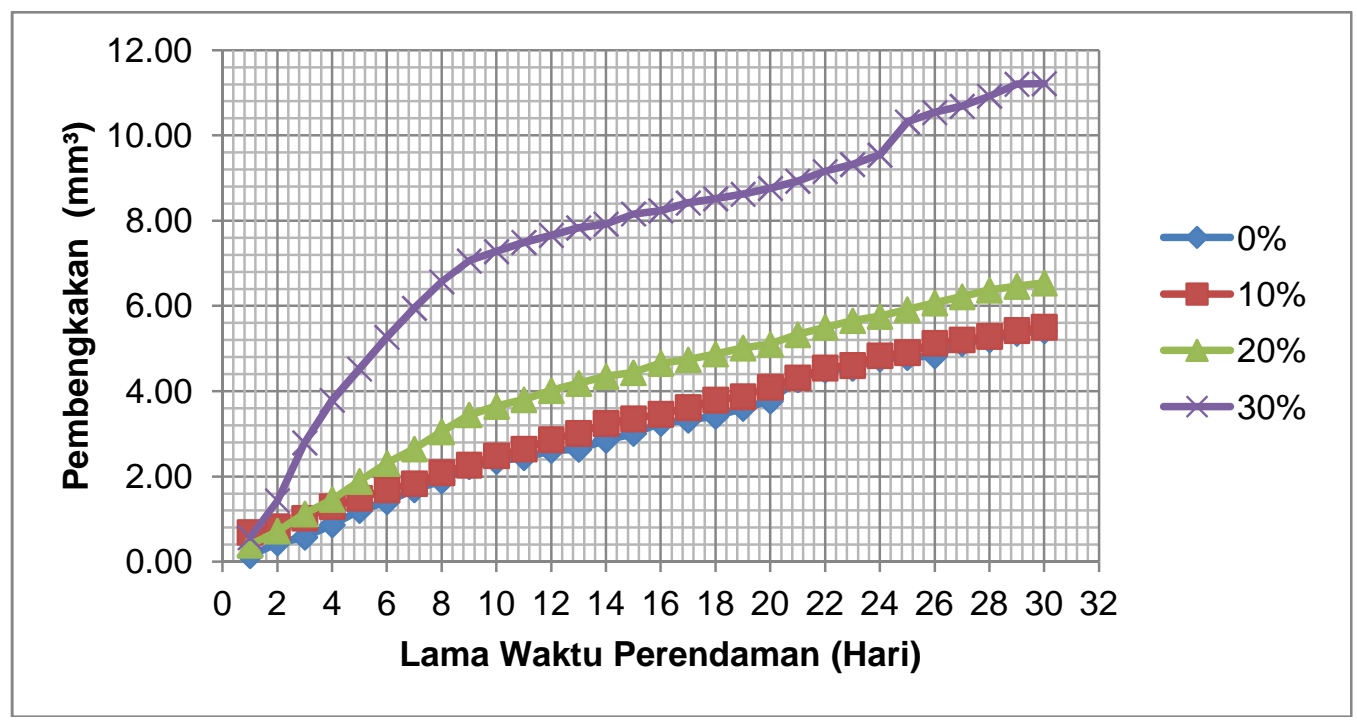

Gambar 2. Grafik Hubungan Antara Fraksi Volume Serat Dan Lama Waktu Perendaman Selama 30 Hari Terhadap Pertambahan Pembengkakan Papan Komposit.

\section{Pembahasan Pembengkakan Papan Komposit Serat Daun Pandan Duri.}

Pengukuran pembengkakan komposit di dalam air menyangkut stabilitas ukuran komposit ketika komposit digunakan di lingkungan ekstrim seperti di luar ruangan yang terkena air hujan atau di lingkungan yang ekstra lemba. Ketika air menempel dikulit komposit maka aliran air ke dalam komposit dapat melewati serat penguat dan diteruskan kedalam komposit. Cacat pembuatan komposit seperti retak mikro, void atau lubang udara, dan anatomi penyusun komposit yang bersifat kapiler dapat mempercepat penyerapan air kedalam komposit sehingga pambengkakan yang terjadi akana semakin cepat pada pengujian pembengkakan pada papan komposit titik konstan terjadi pada perendaman selama 30 hari ini dapat dilihat pada grafik 2 dimana pembengkakan tidak terjadi lagi.

\section{Pengaruh Variasi Fraksi Volume Serat Terhadap Pembengkakan Pada Papan Komposit Serat Daun Pandan Duri.}

Dari hasil pengukuran pembengkakan volume papan komposit pada tabel dan grafik diatas menunjukkan bahwa papan komposit berpenguat serat daun pandan duri mengalami pembengkakan ketika dilakukan perendaman selama 10,20 , dan 30 hari dimana nilai pembengkakan tertinggi terdapat pada variasi fraksi volume serat $30 \%$ yaitu sebesar $7.28 \%, \quad 8.76 \%$, dan $11.22 \%$ Sedangkan pembengkkan komposit terendah terdapat pada variasi fraksi volume serat $0 \%$ atau tanpa serat yaitu sebesar $2.36 \%, 3.77 \%$, dan $5.42 \%$. Hal ini menunjukkan bahwa nilai pembengkakan komposit terus meningkat seiring bertambahnya fraksi volume serat dan lama waktu perendaman karena serat lebih banyak menyerap air dari pada matrik penyusun komposit.

\section{Data Analisis Variansi (Anova) Dua Faktor.} Data pembengkakan komposit dianalisis dengan menggunakan two ways analysis of variance, untuk mengetahui pengaruh dari variasi fraksi volume serat dan lama waktu perendaman serat daun pandan duri dan serbuk gergaji kayu sengon dengan resin polyester terhadap pembengkakan papan komposit. Hasilnya dapat dilihat pada tabel 2. 
Tabel 2 Tabel Two Ways Analysis Of Variance dengan $\alpha=0.05$.

\begin{tabular}{llllll}
\hline Pengaruh variasi & $\begin{array}{l}\text { Jumlah } \\
\text { Kuadrat }\end{array}$ & $\begin{array}{l}\text { Derajat } \\
\text { Kebebasan }\end{array}$ & $\begin{array}{l}\text { Rataan } \\
\text { Kuadrat (MS) }\end{array}$ & $\begin{array}{l}\text { F Hitung F tabel } \\
\text { (Fhit) }\end{array}$ & \begin{tabular}{l} 
(Ft) \\
\hline Volume Serat
\end{tabular} \\
\hline Lama Waktu Perendaman & 10554381.49 & 2 & 5277190.74 & 115.7 & 3.4 \\
\hline Interaksi & 1090176.21 & 3 & 363392.07 & 7.97 & 3.01 \\
\hline Galat & 30532.56 & 6 & 5088.76 & 0.11 & 2.51 \\
\hline Jumlah & 1094667 & 24 & 45611.13 & & \\
\hline
\end{tabular}

Berdasarkan tabel 2 dapat disimpulkan bahwa Fraksi volume serat, Lama waktu perendaman, dan interaksi di antara keduanya berpengaruh terhadap pertambahan volume papan komposit pada perendaman air.

\section{Hasil Pengujian Berat Jenis Papan Komposit Serat Daun Pandan Duri.}

Pengujian berat jenis papan komposit dilakukan dilaboratorium metalurgi dan bahan fakultas teknik jurusan teknik mesin universitas mataram. Pengujian berat jenis komposit dilakukan setelah pengujian penyerapan air dan pembengkakan komposit dengan menggunakan spesimen yang sama, dengan cara membandingkan berat komposit dengan volume komposit sebelum dan setelah perendaman.
Berat jenis merupakan salah satu sifat atau karakteristik papan komposit yang tidak kalah pentingnya dengan sifat dan karakteristik papan komposit lainnya seperti kekuatan tarik, bending, impact, tekan dan lain sebagainya. Jika komposit memiliki berat jenis yang kecil akan bagus sekali digunakan sebagai materian kontruksi, misalnya untuk kontruksi bangunan didaerah-daerah rawan gempa dengan berat yang ringan bila terjadi gempa, energi gempa konstruksi kecil sehingga dapat meminimalisir kemungkinan buruk banyaknya korban gempa. Selain itu komposit yang memiliki berat yang ringan dapat menjadi solusi masalah penghematan energi bisa daipakai untuk komponen kendaraan seperti bahan pembuatan interior dan eksterior pada industri otomotif ataupun perkapalan dengan bobotnya yang ringan bisa meminimalisir penggunaan bahan bakar.

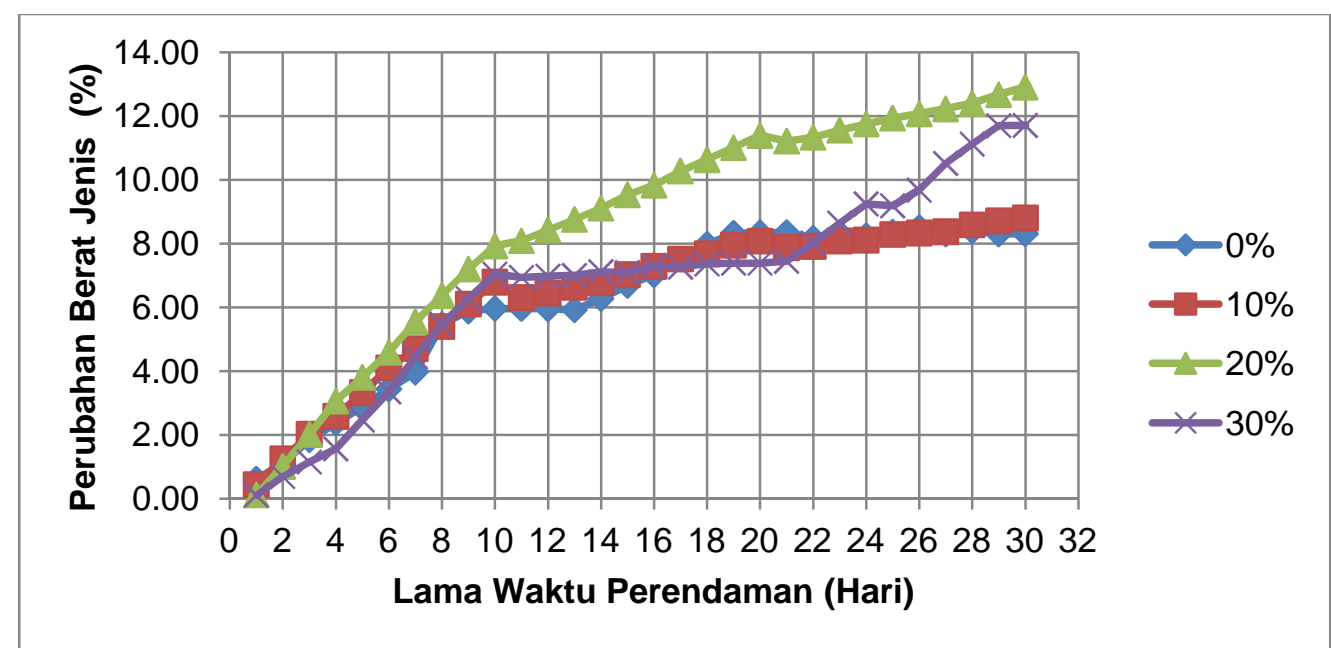

Gambar 3. Grafik Presentase Hubungan Antara Fraksi Volume Serat Dengan Lama Waktu Perendaman Selama 30 Hari Terhadap Perubahan Berat Jenis Papan Komposit.

Pembahasan Hasil Pengujian Berat Jenis. Berat jenis didapatkan dari perbandingan antara berat dengan volume papan komposit. Ada beberapa faktor yang mempengaruhi nilai berat jenis antara lain sifat unsur-unsur penyusun suatu material dan kerapatan material tersebut. Jika suatu material memiliki kerapatan serta berat yang kecil maka akan kecil pula nilai berat jenisnya dan jika material semakin rapat dan berat unsur penyusunnya tinggi maka akan semakin tinggi pula nilai berat jenisnya. Dengan kata lain nilai berat jenis berbanding lurus dengan berat suatu material.

Berat jenis papan komposit yang diperkuat serat daun pandan duri dengan limbah serbuk gergaji kayu sengon dan resin polyester sebagai matriknya bervariasi sesuai 
dengan fraksi volume serat yang ditambahkan yaitu $0 \%$, $10 \%, 20 \%$, dan $30 \%$ pada papan komposit. Karena pengujian berat jenis dilakukan setelah pengujian penyerapan air dan pembengkakan, maka data yang digunakan untuk menentukan perubahan berat jenis komposit dengan membandingkan berat dan volume komposit sebelum dan sesudah pengujian. Dari tabel 2 dengan lama waktu perendaman 10,20 , dan 30 hari, diatas dapat diketahui bahwa perubahan berat jenis papan komposit terendah terdapat pada fraksi volume serat $0 \%$ berkisar antara $5.89 \%$, $8.34 \%$ sampai $8.31 \%$ kemudian untuk pertambahan berat jenis tertinggi terdapat pada fraksi volume serat $30 \%$ berkisar antara $6.73 \%, 7.39 \%$, dan $11.71 \%$.

Pada pertambahan berat jenis titik konstan terjadi pada hari ke 30 sehingga tidak terjadi pertambahan berat jenis pada papan komposit dengan fraksi volume serat $0 \%$, $10 \%, 20 \%$ maupun $30 \%$

\section{Pengaruh Variasi Fraksi Volume Serat Terhadap Perubahan Berat Jenis Komposit Melihat dari penjelasan-penjelasan sebelumnya, variasi fraksi volume serat pada papan komposit tentu akan menyebabkan perubahan pada sifat karakteristik dari komposit ini antara lain perubahan pada berat jenis komposit. Semakin besar fraksi volume yang digunakan pada pembuatan komposit maka akan semakin kecil pula nilai berat jenis dari komposit tersebut, hal ini disebabkan}

karena semakin banyak fraksi volume serat maka penggunaan resin polyester akan semakin sedikit sebagai mana yang kita ketahui bahwa resin polyester memiliki berat jenis yang lebih besar dari pada serat daun pandan duri.

Dari grafk 3 diatas dapat kita lihat papan komposit setelah dilakukan perendaman bahwa semakin besar fraksi volume serat yang digunakan maka berat jenis papan komposit tersebut akan meningkat seiring bertambahnya lama waktu perendaman begitu juga sebaliknya semakin kecil fraksi volume serat yang digunakan maka berat jenisnya akan smakin rendah karena semakin besar fraksi folume serat yang digunakan makan penyerapan air akan semakin besar mengingat serat daun pandan duri dapat menyerap air lebih tiggi dibandingkan matriknya sehingga menimbulkan peningkatan berat dan volume pada papan komposit tersebut sehingga mengakibatkan bertambahnya berat jenis pada papan komposit tersebut.

Data analisis variansi (anova) dua faktor.

Data berat jenis komposit dianalisis dengan menggunakan two ways analysis of variance, untuk mengetahui pengaruh dari variasi fraksi volume serat dan lama waktu perendaman serat daun pandan duri dan serbuk gergaji kayu sengon dengan resin polyester terhadap pertambahan berat jenis papan komposit.

Tabel 3 Tabel Two Ways Analysis Of Variance dengan $\alpha=0.05$.

\begin{tabular}{llllll}
\hline Pengaruh variasi & $\begin{array}{l}\text { Jumlah } \\
\text { Kuadrat (SS) }\end{array}$ & $\begin{array}{l}\text { Derajat } \\
\text { Kebebasan (DB) Kuadrat (MS) }\end{array}$ & \multicolumn{2}{c}{ Rataan } & $\begin{array}{l}\text { F Hitung F tabel } \\
\text { (Ft) }\end{array}$ \\
\hline Volume Serat & 10554381.49 & 2 & 5277190.74 & 115.7 & 3.4 \\
\hline Lama Waktu Perendaman & 1090176.21 & 3 & 363392.07 & 7.97 & 3.01 \\
\hline Interaksi & 30532.56 & 6 & 5088.76 & 0.11 & 2.51 \\
\hline Galat & 1094667 & 24 & 45611.13 & & \\
\hline Jumlah & 12769757.26 & 35 & & & \\
\hline
\end{tabular}

Berdasarkan tabel 3 diatas dapat disimpulkan bahwa Fraksi Volume Serat dan Lama waktu perendaman berpengaruh terhadap pertambahan berat jenis papan komposit pada peyerapan air, sedangkan interaksinya tidak berpengaruh.

\section{Indeks Nyala Api}

Pada penelitian ini, untuk meng hitung indeks nyala api digunakan panjang terbakar rata-rata dari komposit dan kayu Sengon. Panjang rata-rata tersebut diperoleh dengan cara sebagai berikut:

$$
P=P 0-\left(\frac{P 1+P 2+P 3+P 4}{4}\right)
$$




\section{Perbandingan Indeks Nyala Api Komposit Dengan Kayu Sengon}

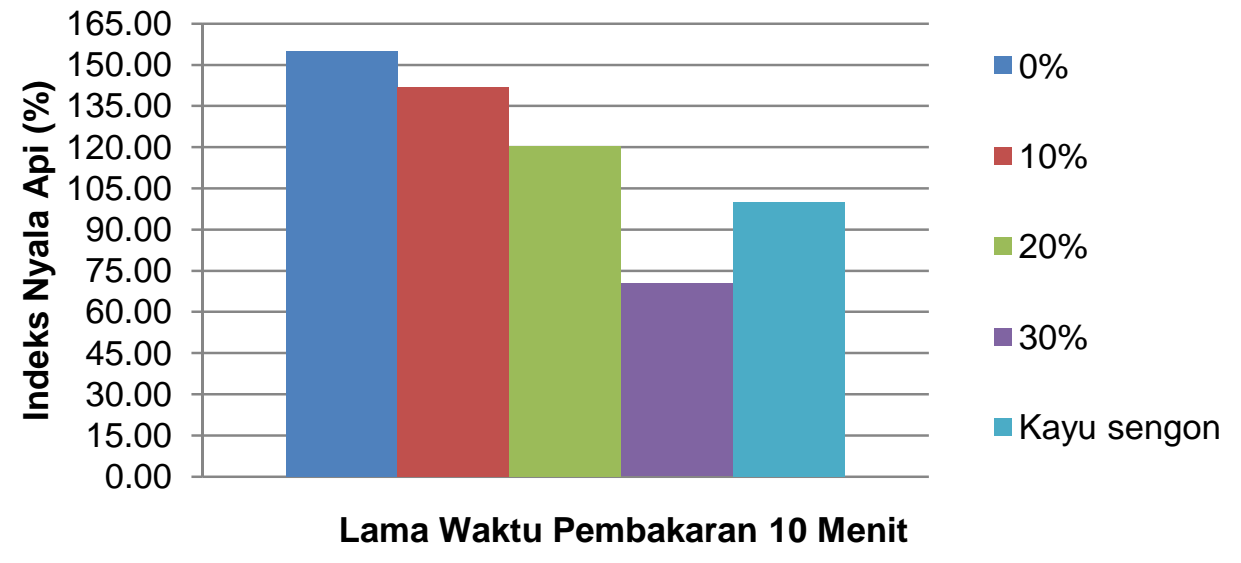

Gambar 4. Grafik indeks nyala api papan komposit dan kayu sengon dengan lama waktu pembakaran 10 menit.

Hasil pengujian indeks nyala api papan komposit berpenguat serat daun pandan duri seiring meningkatnya fraksi volume serat tiaptiap $10 \%$ pada komposit, perambatan nyala apinya akan semakin menurun atau pendek pada permukaan komposit yang terkena api. Maka rambatan nyala api terendah atau terpendek terdapat pada komposit dengan dengan fraksi volume serat sebesar $30 \%$, dan yang tertinggi/terpanjang pada fraksi volume serat $10 \%$.

\section{Pembahasan \\ Papan Komposit Berpenguat Serat Daun Pandan Duri}

Pada indeks nyala api papan komposit berpenguat serat dau pandan duri, fraksi folume serat yang digunakan sangat mempengaruhi rambatan nyala api pada spesimen komposit. Ini terlihat pada variasi fraksi volume serat $10 \%$ serat dengan posisi serat acak, dikarenakan serat tenggelam dan adapula yang melayang ketika sedang dalam proses pencetakan papan komposit dan polyester yang digunakan sebagai matrik masih belum mengering. hal ini disebabkan oleh cara penuangan serat ketika akan dimasukkan ke dalam cetakan.

Ketika serat tertanam ditengah-tengah (ditinjau dari penampang papan komposit), rambatan nyala api relatif tinggi dan cenderung sama dengan nilai rambatan nyala api komposit tanpa penguat serat apapun (komposit 0\% serat). Akan tetapi ketika fraksi volume seratnya ditingkatkan menjadi $20 \%$, hingga $30 \%$, panjang rambatan nyala api menjadi lebih rendah dibandingkan dengan fraksi folume serat $10 \%$. Ini disebabkan karena pada orientasi serat acak, dan fraksi volume serat yang lebih banyak mengakibatkan api lebih lama menjangkau/menjalar karena gumpalangumpalan serat yang terletak/tertanam secara tak beraturan pada papan komposit tersebut.

Diantara fraksi folume serat yang digunakan yaitu $0 \%, 10 \%, 20 \%$, dan $30 \%$ memiliki nilai rambatan nyala api yang lebih rendah. Hal tersebut terjadi karena adanya "intersection" (persilangan) antar pintalan serat dan menimbulkan volume serat yang lebih meningkat, sehingga api pun lebih lambat menggerogoti bagian tersebut.

Data analisis variansi (anova) satu faktor.

Data indeks nyala api komposit dianalisis dengan menggunakan one ways analysis of variance, untuk mengetahui pengaruh dari variasi fraksi volume serat daun pandan duri dan serbuk gergaji kayu sengon dengan resin polyester terhadap ketahanan nyala api papan komposit. Hasilnya dapat dilihat pada tabel 4.14.

Tabel 4. Tabel One Ways Analysis Of Variance dengan $\alpha=0.05$.

\begin{tabular}{|l|c|c|c|c|c|}
\hline \multicolumn{1}{|c|}{ Sumber variansi } & $\mathrm{JK}$ & $\mathrm{Db}$ & $\mathrm{RK}$ & Fhit & F table \\
\hline Fraksi Volum & 17153.06 & 3 & 5717.69 & 59.49 & 3.29 \\
\hline Galat & 1153.33 & 12 & 96.1106 & & \\
\hline Total & 18306.38 & 15 & & & \\
\hline
\end{tabular}


Berdasarkan tabel 4 diatas dapat disimpulkan bahwa Fraksi Volume Serat berpengaruh terhadap Indeks Nyala Api papan komposit pada penyerapan api.

\section{KESIMPULAN DAN SARAN Kesimpulan}

Dari penelitian tentang analisis sifat penyerapan air dan indeks nyala api papan komposit yang diperkuat serat daun pandan duri dengan filler serbuk gergaji kayu sengon dan resin polyester sebagai matriknya, berdasarkan hasil pengujian dan pembahasan yang telah dilakukan, maka dapat disimpulkan:

1. Nilai penyerapan air tertinggi terjadi pada papan komposit serat daun pandan duri dengan fraksi volume $30 \%$ dengan lama waktu perendaman 30 hari yaitu sebesar $16.43 \%$. Nilai persentase perubahan volume atau pembengkakan tertinggi juga terjadi pada fraksi volume serat 30\% dengan lama waktu perendaman 30 hari yaitu $1.05 \%$. Dengan demikian dapat dilihat bahwa semakin besar fraksi volume serat pada komposit maka semakin besar pula nilai pembengkakan dari komposit tersebut. Sama halnya dengan berat jenis, dimana semakin besar fraksi volume serat pada komposit maka nilai berat jenis akan semakin besar.

2. Papan komposit dengan fraksi folume serat $30 \%$ memiliki sifat penyerapan air lebih tinggi sehingga untuk pengaplikasiannya hanya bias digunakan di dalam ruangan yang memiliki tingkat kelembaban yang rendah dan bagian interior pada dunia otomotif.

3. Pada fraksi volume serat sebanyak $30 \%$ untuk penggunaan matriknya lebih sedikit dibandingkan fraksi folume serat $10 \%$ dan $20 \%$ mengingat harga matrik yang digunakan cukup mahal sehingga ini bisa mengurangi biyaya produksi.

4. Papan komposit berpenguat serat daun pandan duri memiliki ketahanan nyala api yang lebih tinggi dibandingkan dengan kayu sengon, hal ini dikarenakan adanya "intersection" (persilangan) antar pintalan serat dan menimbulkan volume serat yang lebih meningkat, sehingga api pun lebih lambat menggerogoti bagian tersebut dengan penggunaan fraksi volume serat $30 \%$ bisa mengurangi rambat nyala api.

5. Indeks nyala api terendah diperoleh dari komposit dengan komposisi serat 30\%, sehingga dalam pengaplikasiannya, komposit jenis ini dapat dikatakan baik, karena tidak memakan bayak polyester dalam penggunaan sebagai matriknya.

\section{Saran}

Kemajuan dunia industri terutama di bidang material saat ini sangat luar biasa. Hal ini tentu menjadi satu alternatif solusi bagi penyelesaian masalah di bidang material, sehingga kedepan perlu dilakukan penelitianpenelitian dengan bahan baku dan metode yang lain. Masih ada beberapa pertimbangan lain yang bisa dijadikan saran atau masukan dalam penelitian ini, yakni antara lain :

1 Resin polyester setelah dicampur dengan katalis dengan cara diaduk sebaiknya jangan langsung dituang kedalam cetakan, tapi didiamkan beberapa saat agar void yang timbul dari permukaan tersebut dapat berkurang.

2 Pada proses pengepresan harus menggunkan alat pengepres yang jauh lebih kuat pembebanannya dikarenakan kurangnya pembebanan dapat menyebabkan void dan cacatnya pada komposit tersebut.

3 Penggunaan katalis sebagai pengering polyester sebaiknya kurang dari $1 \%$ dari volume matrik agar papan komposit tidak menjadi getas.

4 Penggunaan serbuk gergaji kayu sengon sebagai matriknya jangan hanya menggunakan serbuk gergaji kayu sengon saja tapi menggunakan semua jenis serbuk gergaji kayu yang lain.

5 Untuk penggunaan serat sebaiknya menggunakan beberapa jnis serat sebagai perbandingan dan kayu yang digunakan sebagai pembanding sebaiknya kayu yang lebih tahan yerhadap api.

Peneliti menyadari bahwa hasil penelitian ini masih jauh dari kesempurnaan. Oleh karena itu, peneliti sangat mengharapkan penelitian ini dapat dilanjutkan dan dikembangkan para peneliti selanjutnya sesuai dengan standar uji indeks nyala api dan penyerapan air.

\section{DAFTAR PUSTAKA}

[1] Salahudin, Xander, 2012, Kaji pengembangan serat daun pandan dikabupaten magelang sebagai bahan komposit interior mobil, Jurnal Teknik Mesin,

[2] Dina Setyawati, 2011. Komposit Serbuk Kayu Plastik Daur Ulang : Teknologi Alternatif Pemanfaatan Limbah Kayu Dan Plastik. 